\title{
AMERICAN WOMEN AND LEISURE IN THE 1920S ${ }^{1}$
}

\author{
Isabel María García Conesa y Antonio Daniel Juan Rubio ${ }^{2}$
}

\begin{abstract}
Traditionally, the role of women was confined to taking care of the family, and they had little or no voice outside that sphere. The intention was that they would bring up children, keep the home, and look after their husbands who were usually the bread-winners. Consequently, a thorough examination of life in the 1920s will provide a degree of perspective on how women could handle and manage the social advances of the times with regard to their free time activities. We will clearly focus on the efforts of such a group of women in order to get their own leisure activities in society. Therefore, what we should explore throughout this paper is the continuous struggle of women in the United States in the 1920s and the following steps they had to take over. By merely skimming through this article, the reader should gain an accurate and concise notion of what these women had to go through in that awkward period in the United States.
\end{abstract}

Keywords: the new woman, flapper rebellion, social rebellion, spare time, modern woman, status of women.

\section{Título en español: Norteamericanas y ocio en la década de 1920}

Resumen: Tradicionalmente, el papel de la mujer en la sociedad se ha visto reducido al cuidado de la familia con escasa o ninguna repercusión fuera del ámbito doméstico. Se suponía que su papel correspondía al cuidado de los hijos y de sus maridos, y a mantener el hogar familiar. Sin embargo, un cuidadoso estudio de la vida en los años veinte nos proporcionará una amplia perspectiva sobre la manera en la que las mujeres manejaron los avances sociales de la época. Intentaremos dar un claro enfoque sobre los esfuerzos de dichas mujeres por obtener su reconocimiento social. Lo que se intentará demostrar será la continua batalla de las mujeres en los Estados Unidos en los años veinte, y todas las dificultades que tuvieron que sortear. Simplemente ojeando este artículo, el publico lector podrá obtener una visión concreta y precisa de la lucha de estas mujeres en esa época desenfrenada en la historia de los Estados Unidos. Palabras clave: la nueva mujer, la rebelión "flapper", la rebelión social, tiempo libre y ocio, la mujer moderna, el estatus de la mujer.

\footnotetext{
${ }^{1}$ Date of reception: 15/07/2013

Date of acceptance: $14 / 10 / 2013$

${ }^{2}$ Lecturers, Departamento de Integración, Centro Universitario de la Defensa San Javier - UPCT, Murcia, Spain; $\bowtie$ isabelmaria.garcia@ cud.upct.es and antonio.juan@cud.upct.es.
} 


\section{Introduction}

The decade known as "The Roaring Twenties"3 hide behind that magnificent name a time of great social and cultural change in the United States. The presidential elections of 1920 gave office to the Republican candidate Warren Harding, and in this decade the latter presidents Calvin Coolidge and Herbert Hoover will also follow the former, all belonging to the Republican Party, the one in power along this period.

This decade, so crucial in the history of the United States, is marked by such major social events as the rebellion of women, the concept of the new "flapper" woman, and the fight against racism and corruption. Technological advances also propelled the supposed economic prosperity of the period. As the American author Judith S. Baughman wrote: "In such a golden decade, in which apparently almost anything was permitted, women began to explore certain domains which had previously been vetoed to them" (Baughman 1996: 159).

However, this time of apparent economic boom ended with the stock market crash of 1929 and the further collapse of both the Wall Street market and the US financial system alike. This fact spread panic among the American people and plunged the country into the worst economic depression in its entire history. The so-called "jazz age" marked a period in American history characterized by a change in social values. As the American historian Paul Johnson put it: "In the twenties, America had many things to be horrified, captivated, or fascinated, but mostly had jazz" (Johnson 1997: $155)$.

With the passage of the $19^{\text {th }}$ Amendment to the Constitution in $1920^{4}$, women finally won the right to vote, something for which they had been fighting for so long.

\footnotetext{
${ }^{3}$ The Roaring Twenties is a term sometimes used to refer to the $1920 \mathrm{~s}$, characterizing the decade's distinctive cultural edge during a period of sustained economic prosperity. "Normalcy" returned to politics in the wake of hyper-emotional patriotism during World War I, jazz music blossomed, the flapper redefined modern womanhood, and Art Deco peaked. Economically, the era saw the large-scale diffusion and use of automobiles, telephones, motion pictures, and electricity, unprecedented industrial growth, accelerated consumer demand and aspirations, and significant changes in lifestyle and culture.

${ }^{4}$ The Nineteenth Amendment (Amendment XIX) to the United States Constitution prohibits any United States citizen to be denied the right to vote based on sex. It was ratified on August 18, 1920. The
} 
Thus, a generational gap began to form between the new woman of the twenties and the older generations of women who were constrained by rigid social norms. Less enclosed by the rigid conventions of bizarre Victorian standards, the new woman had a greater freedom to obtain public recognition in various fields as we shall examine in the article.

The new woman of the 1920s openly challenged conventional gender roles and consequently faced the hostility from men who refused not only the public presence of women in society, but also the alleged decline of morality. This new woman, accordingly, represented the trend of young girls expressing themselves with certain autonomy. Nevertheless, the powerful conservative forces of society did already vehemently oppose to the new role of women in society. Many of them were alarmed by what the phenomenon of the new woman meant. Even in popular magazines of the times, the writers asked for a return to the old moral codes of behaviour that had previously repressed the younger generation of women.

The concept of the new woman also had a number of sexual connotations, reflecting a change of ideas about the female sexuality. Led by young girls, mostly coming from a middle-class background, but also including women from all social levels, a new sexual revolution was beginning to take shape in the American society. However, the new woman embodied an emblem of change and a source of strong controversy among their contemporaries who were threatened by new liberal attitudes to gender. A gender battle was then settled down amongst both factions of society in which the new social trends were just beginning to flourish.

\section{The new woman of the twenties}

The issue under questioning is where the social status of the new woman was exactly put forward in the twenties. The most prominent change was her increased presence in public life. Whilst the lives of women in previous generations revolved

Constitution allows the states to determine the qualifications for voting, and until the 1910s most states disenfranchised women. The amendment was the culmination of the women's suffrage movement in the United States, which fought at both state and national levels to achieve the vote. 
around the family home, the new woman ventured into different professions which had traditionally been regarded as male-owned. However, they did not equal men at odds as they were still economically and politically dependent on them at the beginning of the century. Yet, unlike their Victorian contemporaries, they did not sit idly by. They struggled to find their own place in society instead. Unsurprisingly, certain pressure groups, like the Ku Klux Klan (K. K. K.) ${ }^{5}$, strongly opposed the new role of women.

The unambiguous answer to these social changes came in the form of a "flapper" upheaval on the part of women. It is in this social context in which the term had its underlying principle. The lifestyle of young women of the twenties surprised their elders. Young people looked for answers in places that were once considered unthinkable, both morally and physically, by society.

After World War I, women were as eager as men to avoid returning to the traditional social code and roles prior to the war. This generation of young women broke with the old traditional value system. Quoting the American Professor George H. Douglas: "They devoted themselves just to happily enjoy life and the abundant free time of the period" (Douglas 1986: 87). Various prestigious authors such as F. Scott Fitzgerald or Anita Loos, and renowned artists as John Held Jr., Russell Patterson, Ethel Hays or Faith Burrows used the term "flapper" for the first time in the United States. Along their works and creations, they half created or half reproduced the image and style that these loose girls reflected.

The famous novelist F. Scott Fitzgerald described the ideal "flapper" with the following definition: “A lovely girl, expensive, and about nineteen” (Hatton 2000: 145). The artist John Held Jr. created an image of these young women by drawing girls who were wearing high-heeled shoes with laces that made a loud noise when walking. The so-called "flapper culture" reflected significant changes in the lives of American women. An open-minded lifestyle suggested new approaches for women, mostly

\footnotetext{
${ }^{5}$ The Ku Klux Klan (KKK), informally known as the Klan, is the name of three distinct past and present far-right organizations in the United States, which have advocated extremist reactionary currents such as white supremacy, white nationalism, and anti-immigration, historically expressed through terrorism. Since the mid-20th century, the KKK has also been anti-communist.
} 
neglected, and in constant search of pleasure. Many young girls were then able to follow an independent lifestyle.

Quoting the author Ellie Laubner: "The term flapper of the twenties refers to a specific kind of woman wearing skirts, cutting her hair to the male style, listening to jazz, and displaying a disdain for what they considered it was a misguided behaviour" (Laubner 2000: 78). Although many scholars have attempted to properly define the concept of "flapper", perhaps one of the most accurate definitions is the one offered by social critic and editor Henry L. Mencken: "A little silly girl, full of wild guesses, and inclined to rebel against the precepts and admonitions of their elders" (Andrist 1970: 130).

The so-called "flapper girls" even had their own jargon. Their dialect reflected both their promiscuity and their drinking habits. This dialect also mirrored their main worries since they had many different ways to express approval or refusal. In fact, many of the terms that are still used in modern American slang actually originated in the twenties. The author Kathleen Gourley gathered together in 2007 a complete list of the most common slang words of the twenties.

For the very first time, these women flaunted about the excessive use of makeup. Cosmetic products, which had not been previously accepted in American society for their connection with prostitution, became extremely popular in the everyday lives of these women. In addition, they drove fast sport cars at high speed ahead the newly constructed highways across the nation, disobeying the social and sexual codes. Therefore, they were considered reckless by society. Accordingly, these girls smoked when only men had done it before. But smoking was not the most outrageous action of these rebel girls. In their spare time, besides smoking, they drank alcohol in a time when the United States had banned alcohol by means of the $18^{\text {th }}$ Amendment ${ }^{6}$.

With legal cabarets closed, speakeasies became rather prolific and popular at the time. The discrepancy between the respect for the law and the actual consumption of

\footnotetext{
${ }^{6}$ The Eighteenth Amendment of the United States Constitution established prohibition of alcoholic beverages in the United States. The Amendment was the first to set a time delay before it would take effect following ratification, and the first to set a time limit for its ratification by the states.
} 
alcohol everywhere led to a widespread disdain for authority, another characteristic image of the twenties. Young girls, especially, headed a sexual release by talking about sex naturally. Many of the ideas that drove this change in sexual behaviour were already latent in the intellectual circles of New York before World War I, with the works of writers such as Sigmund Freud, Havelook Ellis, and Ellen Key.

The great thinkers of the time held the opinion that sex was not only central to the human experience but also that "women were sexual beings with human impulses and desires just like men, and to restrain those impulses was self-destructive" (Woloch 2002: 202), an opinion shared by the Professor of American Studies, Nancy Woloch. During the twenties, these ideas had deeply rooted into the American society.

Although they were often labelled as misguided, superficial, and vacuous, the truth is that many of them were young educated women who were simply coping with the disappointment of the society of the time whilst trying, at the same time, to forge their own steps into the new society. As the historian Frederick L. Allen wrote: "They were imbued into a spirit of eating, drinking, and being merry for tomorrow they shall die" (Allen 1931: 94). Immortalised in movies, the most famous actresses of the decade identified themselves with the "flapper lifestyle". Among them, we can mention the following as the most representative actresses: Olive Borden, Clara Bow, Louise Brooks, Joan Crawford, Norma Shearer, Norma Tallmadge, Olive Thomas, and Alice White.

Despite its enormous popularity, the "flapper" lifestyle that characterised the period could not survive the stock market crash and the following Great Depression ${ }^{7}$. Its lively hedonist attitude could not find a place amid the economic hardships of the thirties. More specifically, this new decade brought out a conservative reaction and a religious revival which set out to eradicate the liberal lifestyle and attitudes of the Roaring Twenties.

\footnotetext{
${ }^{7}$ The Great Depression was a severe worldwide economic depression in the decade preceding World War II. The timing of the Great Depression varied across nations, but in the US it started in 1930 and lasted until the late 1930s or middle 1940s. It was the longest, most widespread, and deepest depression of the 20th century.
} 


\section{The modern woman and the new leisure activities}

What we have been analysing insofar was also mirrored by the disdain shown towards social attitudes and conventions. Such disregard resulted into the active participation of women in the recreation and leisure activities of the decade that, until then, had been vetoed to them. We shall refer along this section to such leisure activities as crafts, sports, music and dance, and fashion.

Regarding the field of crafts, they were logically passed on from mother to daughter and became a very popular leisure activity in the 1920s. This was particularly significant, as the Professor of American History Alice Kessler-Harris correctly states: "This craft was meant to be used as a profitable employment, especially in the long, cold winter nights" (Kessler-Harris 2003: 338).

From the traditional crafts of sewing such as knitting, crocheting, quilting, or embroidering, women could get a bonus income to the family in addition to that of their husbands. Besides, there were also a number of other popular activities for them such as beads and stained glass. Yet the real significance of this traditional craft in the decade is that, beyond being a usual and common leisure activity, it meant that women obtained a regular economic salary. Needless to say, this profit was done with the subsequent initial reluctance of men who had previously been the only regular bread-winners at home.

However, once surpassed, it was felt that the money earned from this new activity served mainly to satisfy their whims rather than to cover certain basic needs. But as the American historian Dorothy M. Brown reflected: "It was still unimaginable to society that women yielded the economic support of the family" (Brown 1987: 160).

On the field of sport, spectator sports attracted huge audiences of public in the twenties, exceedingly stressing the massive influx of women to these events. The whole country longed for sport heroes in an increasingly impersonal society, and sports provided such entertainment. Although team sports (baseball, American football, and basketball) quickly flourished at those times, citizens turned their attention to the 
individual stars of each sport ${ }^{8}$. These were athletes whose talents made them stand out from the rest and whose qualities many young girls hurriedly encouraged to emulate.

The massive turnout of spectators to the various shows made possible the growth of a completely novel professional sports industry that, until then, was in its early stages. In the twenties, people had money to buy tickets for various sporting events and, above all, to buy the clothing of their favourite teams or players. The direct consequences of this massive attendance of women to the assorted sporting events that were held throughout the entire country were the active participation of women in certain individual sports such as tennis or golf on the one hand, and the rapid and huge growth of the parallel sport industry on the other.

Not only the first female tennis and golf schools quickly flourished, but also the sport industry saw an incredible opportunity to do business by means of launching new lines of casual women's clothing. This new attitude even got to the cover page of some mass media means, as the American Professor Carolyn Kitch reflected in 2001. This phenomenon had its social relevance in the 1920s because, up to then, the presence of women in sports had been nothing but symbolic. Thus, the public image of a woman attending a sporting event or playing on a golf or tennis court became usual later on this decade, which meant a revolution for a society in a constant state of change.

As for the areas of music and dancing, if the so-called "flapper girls" provided with some of the most typical images of the era, jazz music was the keynote. Both in speakeasies and in nightclubs, its syncopated rhythms articulated the spirit of rebellion which characterised so much the image of the twenties. The jazz age saw the nationwide growth of this type of music coming directly from the African-American culture. As the American author Joy Hakim expressed: "The jazz music was commonly associated with everything that looked like modern, sophisticated, and decadent" (Hakim 1995: 84). This music was very different from any other type of music that had been heard before.

\footnotetext{
${ }^{8}$ In the world of sports, the names of five famous athletes from the 1920s are legendary: Babe Ruth (baseball), Red Grange (football), Jack Dempsey (boxing), Bill Tilden (tennis), and Bobby Jones (golf).
} 
Jazz was considered as an evil influence on the American youth with its conventional rhythms and strange melodies. However, despite all the common negative shared opinions it had, jazz became wildly popular in the decade, proliferating in dance halls across the entire nation. A new generation of dancers, freed from the constraints of tight corsets and long dresses that had characterised the earlier Victorian era, swayed to the new rhythms of music. The new styles of dance were an important part of any worthy social entertainment activity or party. New dancing schools also flourished across the country in order to teach young girls to dance while, at the same time, some churches used the new dance to attract them. Dancing was a new popular social activity, especially among young women.

The reasonable result of this recent interest was the fact that dance marathons were organised every weekend across the country. Young girls introduced their own styles of fashion with short hair, short skirts, and tight hats. The new dance began to actively use the upper part of the body for the first time since the young girls began to shake their hips in a novel dance called the "shimmy". Young girls jumped into a wild dancing without restrictions and started to move or use more parts of their body. Yet the dance that typically symbolised the 1920s was the "Charleston", which was presented to the public in 1923 and, even nowadays, it remains as a symbol of the jazz age. As the historian Angela Latham wrote: "The flapper girls with their knees together and folded hands were the best ones that staged this original kind of dance" (Latham 2000: 57).

Finally, the field where more significant advances were seen and where the social and cultural rebellion had more reflection on the new woman was in the field of fashion. Fashion had always been influenced by the mode of transport that people normally used to move to work, the architecture of the time, and the customs of people. And so it obviously happened in the twenties, although with some variations as we shall explain. The reflection of this lifestyle had its immediate effect on the young women's fashion of the twenties that was as much a trend as a social statement, breaking with the rigid Victorian conventions of the previous generation. These rebellious young girls stuffed into dresses reaching to their knees, and making a conspicuous showing of arms and legs. In line with the progress in other areas of leisure, clothing developed into a 
much closer relationship with the art of the decade, which was reflected in a greater sense of freedom, and resulting in simple yet elegant designs with carefully selected fabrics as well as with the intelligent use of the right colour.

The so-called "flapper style" was not just a female fashion style but it also introduced several significant changes in the perception of women in society. They were the splendid women of a new era exercising their newly gained voting freedom, staying up all night, and frequenting clubs and parties. Haute couture, until the twenties, had almost exclusively been aimed at the wealthiest women in society. But since the design of the new dresses began to be much less complicated than the ones used and worn in earlier fashions and decades, women were much more successful making costumes at home.

As a consequence, the women's clothing became looser, the bust was suppressed, the waist disappeared and the shape of the shoulders widened. The new silhouette emphasised a flattened chest which accordingly eliminated the feminine curves. From this time forth, the female characteristic fashion in the twenties consisted of beautiful costumes combined with various decorative accessories. Hats, shoes, socks, bags, dresses and jewellery joined in harmony so as to create a unique and elegant feminine style. Fashion for women underwent dramatic changes along this decade for some sections of the society. New and colourful fabrics echoed the joy felt by a population tired of the war after the end of hostilities.

The garments were shorter, lighter and brighter than ever. Both shoes and stockings claimed right now their importance on being visible for the very first time. Silk stockings were designed from all the colours of the rainbow to match them with the clothes of women who had their own distinctive style. Fashion designers now played with fabric colours, textures and patterns in order to create a totally new style. The great fashion designer of the twenties was Gabrielle "Coco" Chanel ${ }^{9}$. The silhouette of her clothing designs came to epitomize the characteristic style of the twenties. The work of

9Gabrielle "Coco" Bonheur Chanel (1883-1971) was a French fashion designer and founder of the Chanel brand. She was the only fashion designer to appear on Time magazine's list of the 100 most influential people of the 20th century. Along with Paul Poiret, Chanel was credited with liberating women from the constraints of the "corseted silhouette" and popularizing the acceptance of a sportive, casual chic as the feminine standard in the post-World War I era. 
other famous designers of the period, as compared to hers, looked outdated and oldfashioned. "Coco" Chanel promoted the fashion styles that are still today commonly associated with the "flapper fashion". She worked in neutral tones of beige, cream, navy, and black in soft fabrics cut with simple shapes that did not require corsetry or waist definition. Clothes were made for easy comfort and ease of use, making them revolutionary and quite modern at those times.

As a result, new sewing courses proliferated for the women who followed the new fashion trends and did not want to pay retail prices. Many women turned to fashion as a vocation to financially support their families, or to earn some extra money with which to meet the new luxuries of the time. Trouser suits, hats and canes gave women a sleek look avoiding the vagaries of fashion. Consequently, undergarments of women changed because of this new move towards the practical clothing corsets, which were smaller and more flexible, leading finally to the panties. Without the restriction of the old-fashioned corsets, young girls wore simple bras with the purpose of holding their bust while dancing.

The new high-cut dresses gave women more confidence in themselves and in the shape of their body, allowing them to move freely around the dance floor and just exposing the right amount of skin in order to attract the attention of men. Immediately, the first fasteners designed to flatten and reduce the appearance of the bust began to be sold, configuring the image of the modern woman. The first clips of the twenties were white cotton handmade and were little more than bras with additional clearance for the bust. When it was finally recognised that women had different bra cup sizes, the sales of bras doubled with the new and exotic designs.

The "flapper girls", who were fashionable in the decade, wore dresses getting shorter with a straight loose silhouette. By 1927, the seams had already been raised above the knees, leaving some parts of the legs in sight. The flat chested slender body and the bronzed face of a young girl became the desired silhouette by many young girls of the twenties. Health and beauty clubs helped women refine their silhouettes all along the decade. 
These trends both in clothing and in accessories were also reflected in the different hairstyles of the time. For the first time in the United States, the "Bob" hairstyle was introduced by Louise Brooks in 1920. Hairstyles of the Hollywood stars were copied by women all around the world, and several women's magazines published articles on how to achieve that look. The particular way in which women wore their hair styles determined not only the fashion but also the cutting method. In this decade, male hair styles became fashionable also for women, as in the case of the so-called "Shingle Bob". And the author that best reflected all these trends in hairstyle was Professor of Art Whitney Chadwick in 2003. The public image of the new woman consisted of drastic and surprising changes in both their clothes and hair. Almost all women's wear was shortened and lightened in order to facilitate their movement around. The new dances of the time also required that women were able to move freely all over the dance floor.

\section{Conclusions}

The economic boom of the twenties made possible the appearance of a taste for new free time activities that were commonplace at this time. Among these activities, going to movies, dancing at parties, attending sporting events, or dressing in the latest fashion were the favourites. The characteristic feature of this decade was the rebellion of the new woman and the change in social habits that totally transformed the American society.

This decade, so crucial in the history of the United States, is marked by such major events as the rebellion of young women, the concept of the new "flapper" woman, the fight against racism and corruption, and the technological advances which propelled the alleged economic prosperity of the period. Women got the right to vote along this decade and fought against the repression and the conservatism that constrained them. They wanted a greater social equality and even though they seemed to get it, they were still far behind men in many areas. 
Although many women participated in the expansion of their public role, they accepted the change in many different ways. The symbol of the new woman was an accumulation of different aspects of women across the country. Amidst them, we can find dancers, athletes, musicians, and professionals in almost all sectors of society.

Thus, the Roaring Twenties redefined the status of women and their new attitude towards leisure activities and towards society itself. A new woman evolved, for whom it was more socially acceptable to smoke and drink in public. On the other hand, it was also increasingly accepted that they would fall down into wild dancing, they would have a much shorter hair style, or they would make excessive use of make-up when until then it had almost been vetoed.

The new woman of the twenties challenged conventional roles of gender and faced the open hostility of men who refused both the public presence of women in society on the one hand, as well as the alleged decline of morality on the other. This new woman represented the trend of many young girls expressing certain personal autonomy.

\section{References}

Allen, Frederick L. 1931. Only Yesterday: An Informal History of the 1920s. New York: Harper \& Brothers.

Andrist, Ralph K. 1970. The American Heritage: History of the 20's and 30's. New York: American Heritage Publishing.

Baughman, Judith S. 1996. American Decades: 1920-1929. New York: Manly Inc.

Brown, Dorothy M. 1987. Setting a Course: American Women in the 1920s. Boston: Twayne Publishers.

Chadwick, Whitney. 2003. The Modern Woman Revisited. New York: Rutgers University Press.

Douglas, George H. 1986. Women of the 20s. New York: Saybrook Publishers.

Gourley, Kathleen. 2007. Flappers and the New American Woman. Minneapolis: Twenty-First Century Books. 
Hakim, Joy. 1995. War, Peace, and All That Jazz. New York: Oxford University Press.

Hatton, Jackie. 2000. Flappers. New York: St. James.

Johnson, Paul. 1997. History of the American People. Phoenix: Phoenix Giant.

Kessler-Harris, Alice. 2003. Out to Work: A History of Women in the United States. New York: Oxford University Press.

Kitch, Carolyn. 2001. The Girl in the Magazine Cover. Chapel Hill: University of North Carolina Press.

Laubner, Ellie. 2000. Fashions of the Roaring '20s'. New York: A Schiffer Book for Collectors.

Latham, Angela. 2000. Posing a Threat: Flappers, Chorus Girls and Other Brazen Reformers of the American 1920s. New York: Wesleyan.

Woloch, Nancy. 2002. Women and the American Experience: A Concise History. New York: McGraw-Hill. 